\title{
KOCKÁZATELEMZÉSI MÓDSZEREK SZEMLÉLTETÉSE A DIÁKÉLET EGY PÉLDÁJÁN KERESZTÜL
}

\section{DEMONSTRATION OF RISK ASSESSMENT METHODS THROUGH A STUDENT LIFE PROBLEM}

\author{
Tráj Krisztina ${ }^{1}$, Pokorádi László ${ }^{2}$ \\ ${ }^{1}$ Óbudai Egyetem Bánki Donát Gépész és Biztonságtechnikai Mérnöki Kar, egyetemi \\ hallgató, H-1081 Budapest, Népszínház u. 8.; Tel.: +36 20 2900595; \\ krisztinatraj@gmail.com \\ ${ }^{2}$ Óbudai Egyetem Bánki Donát Gépész és Biztonságtechnikai Mérnöki Kar, egyetemi \\ tanár, H-1081 Budapest, Népszínház u. 8.; Tel.: +36 30 9194929; \\ pokoradi.laszlo@bgk.uni-obuda.hu
}

\begin{abstract}
Nowadays, the quality of products or services, reliability and safety of technical systems and processes are playing an increasingly important role. Our aim is to elaborate illustrative samples, which facilitate the understanding of different risk assessment techniques through course of lectures of Technical reliability at the Óbuda University. The study presents the illustrative examples of analytical methods through a student life problem.
\end{abstract}

Keywords: risk analysis; FTA; Ishikawa analysis; bow-tie analysis.

\section{Összefoglalás}

Napjainkban egyre fontosabb szerepet játszik a termékek vagy szolgáltatások minősége, a technikai rendszerek, valamint folyamatok megbízhatósága és biztonsága. Ezért olyan szemléltető példasor kidolgozását tüztük ki célul, mely elősegíti a különböző kockázatelemzési módszerek megértését az Óbudai Egyetemen oktatott Műszaki megbízhatóság tantárgy előadásai során. A tanulmány a kidolgozott elemzési módszereket szemléltető példákat mutatja be a diákélet egy problémáján keresztül.

Kulcsszavak: elemzés; FTA; csokornyakkendö elemzés.

\section{Bevezetés}

Napjaink talán két legnépszerübb szavává vált a biztonság és a minőség. Szerepeljen az egy reklámban, vagy legyen bármilyen cég szlogenének egy eleme, valamilyen megmagyarázhatatlan módon megbízhatóságot sugall felénk. Akárhol hallják, olvassák az emberek, úgy érzik, biztonságban vannak, védve érzik magukat a rájuk leselkedő veszélyes dolgok ellen. Ennek persze tudatában vannak a vállalatok is, akik termékeiket, szolgáltatásaikat eme büvös szóval felruházva teszik a vevők, ügyfelek számára még vonzóbbá.

De mielőtt e két szó negatív érzéseket keltene bennünk, lássuk, milyen pozitív dolgok is valójában. A technikai problémáktól kezdve egészen a magánéletünkig rengeteg problémával, elkövethető hibával, kockázattal találkozhatunk. Ezek elkerülése érdekében rengeteg eszköz áll rendelkezé- 
sünkre. A hibaelemző módszerekkel az úgynevezett nem-kívánt események bekövetkezésének esélye nagymértékben csökkenthető - sőt, legkedvezőbb esetben meg is szüntethető. Alkalmazásukkal felkészültebbek, így eredményesebbek lehetünk. Gondoljunk csak bele: ha bármilyen folyamat megkezdése előtt már kielemezzük a lehetséges kockázatokat, hibaokokat és még időben meggátoljuk ezek bekövetkezésének valószínüségét - netalán teljes mértékben meg tudjuk akadályozni azokat -, rengeteg időt, energiát, pénzt spórolhatunk meg.

Tanulmányunk egy egyszerü, hétköznapi egyetemi példán - a vizsgákon történő bukások kockázatelemzésén - keresztül röviden bemutatja, milyen célt szolgálnak, hogyan müködnek egyes hibaelemző módszerek. Ezúton is felhívja a figyelmet arra, hogy milyen jelentős szerepe van a kockázatelemezésnek és a tanulásnak.

\section{A szemléltetett eljárások}

\subsection{Hibafa elemzés}

A hibafa elemzés célja a rendszerszintű veszélyek előfordulását előidéző feltételek, tényezők, úgynevezett elemi okok, megállapítása. A vizsgálat első lépése az, hogy megfogalmazzuk az úgynevezett csúcseseményt. Ezt követően felkutatjuk a csúcsesemény kiváltó okait, majd, a kapott eredmények alapján elkészítjük a hibafát: az analízis eredményeit fastruktúra formában ábrázoljuk, így logikussá, áttekinthetővé válik a vizsgálat egésze. A fö-esemény a kiinduló pont, majd fokozatosan haladva vázoljuk az al-eseményeket, melyek a hibát okozták. Utólag ezt kibővíthetjük megbízhatósági számításokkal is [1]. A megbízhatósági mérőszámok szakkönyvek táblázataiból olvashatóak ki, ennek hiányában a gyakorlati tapasztalat az irányadó. Következő feladatunk a rendszerhibák és hibaláncolatok minőségi és mennyiségi szempontból való kiértékelése. Ezen elemzések eredményei alapján kirajzolódnak a rendszer gyenge pontjai.

A rendszer megbízhatóságával kapcsolatban mérőszámok nélkül is vonhatunk le következtetéseket. Egyik lehetőség, hogy megkeressük a kritikus (minimális) láncokat. Ez olyan hibakombináció, mely a föesemény bekövetkezését okozza - a legkisebb számú meghibásodás mellett. Tehát ez a legrövidebb lánc. Így kimutatható a hibafa leggyengébb ága.

Összegezve: a hibafa analízis minőségi (kvalitatív) és mennyiségi (kvantitatív) elemzésre egyaránt alkalmas [2].

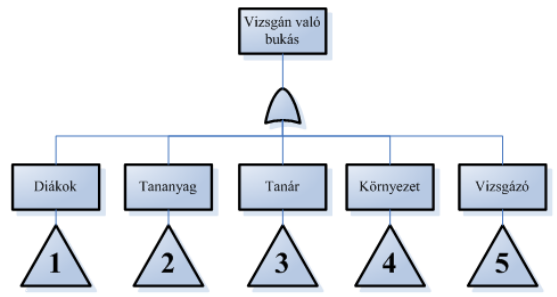

1. ábra. A hibafa elemzés egy részlete [2]

Az események egymáshoz logikai müveleteken keresztül kapcsolódnak. Ezek a Boole-féle logikai kapuk. A fóesemény az aleseményeket és a fóeseményt összekapcsoló, úgynevezett logikai főkapu kimeneti eseménye. Ekkor az al-eseményeket bemeneti eseményeknek nevezzük [2].

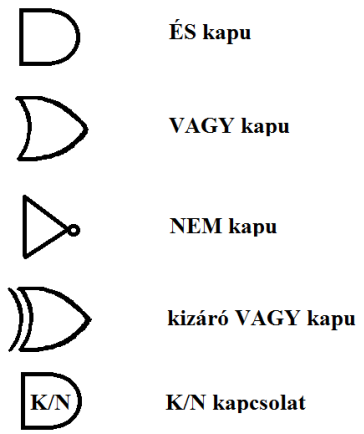

2. ábra. Boole-féle logikai kapuk [2] 


\subsection{Ishikawa elemzés}

Ennek az elemzésnek számos elnevezése ismert: Ishikawa, ok-okozati, halszálkaelemzés, illetve angol nyelvü szójátékként létrejött a „Fishikawa” megnevezés is.

Elsősorban a probléma meghatározására van szükség a „MI?”, „HOL?”, „MIKOR?”, „MIÉRT?” kérdések segítségével. Ezután az esetlegesen fellépő hibaokokat tárjuk fel probléma, fö-ok, okok sorrendben. Harmadik lépésben azonosítjuk, súlyozzuk az okokat és ábrázoljuk a halszálka diagramot. A hal feje az ábra jobb oldalán helyezkedik el, ide írjuk a problémát, mint okozatot. A hal gerincéből kiinduló szálkákon a fö befolyásoló okcsoportokat szemléltetjük, az egyre kisebb szálkákon pedig az alsóbb rendủ hibákat ábrázoljuk - egészen addig, míg el nem jutunk a gyökér okokig [2]. Tehát a probléma megszüntetéséhez az okok felismerése és elemzése alapján juthatunk el.

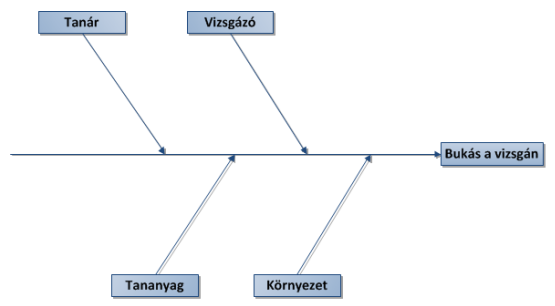

2. ábra. Az Ishikawa elemzés egy részlete [2]

Az elemzés során kapott eredményeket növekvő részletességgel ábrázoljuk. a hierarchikus felépítésnek köszönhetően a vizsgálat menete mindenki számára egyszerüen értelmezhető. A halszálka-elemzéssel végzett analízis alaposabb elemzést tesz lehetővé, mint az általános mérnöki gondolkodásból adódó elemzés [2].

\subsection{Eseményfa elemzés}

Az eseményfa elemzés a hibafa módszerrel szemben induktív, azaz ellentétes irányú eljárás, előremenő gondolkodású folyamat. A vizsgálat célja egy adott kiváltó esemény különböző feltételek melletti hatásainak vizsgálata.

$\mathrm{Az}$ analízist leginkább mennyiségi kockázatelemzésnél alkalmazzák. Az eseményfa elemzés olyan potenciális balesetek kimenetelét értékeli, amelyek a kiváltó eseménynek nevezett valamilyen készülék meghibásodás vagy technológiai zavar után következhetnek be.

Az eseményfa esetében is - ahogy a hibafa-analízisben is - van lehetöség az eseményláncok logikai és időbeli lefolyásainak minőségi és mennyiségi kiértékelésére is. Ehhez azonban ismerni kell az úgynevezett kezdeti esemény gyakoriságát és az eseményfa elemeinek bekövetkezési valószínüségét. Ezen adatok ismeretében a valószínüségelmélet segítségével kiszámíthatóak a különböző eseményláncok valószínüségei [3].

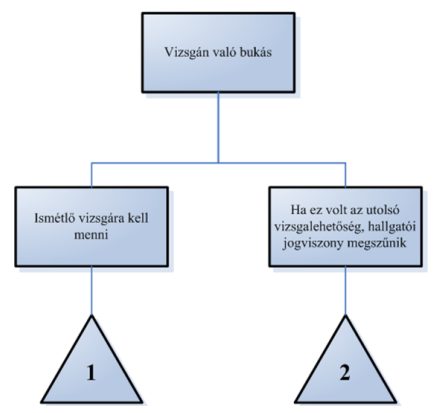

3. ábra. Az eseményfa elemzés egy részlete [3]

Az eseményfa alkalmazása nehézségekbe ütközhet a sok, egy időben bekövetkezö eseményt tartalmazó rendszerekben. Ez esetben alkalmazását hibafa-analízissel kombinálják. Ilyenkor az eseményfában szereplő, elágazásokat okozó események különálló hibafák csúcseseményei [3].

Első lépésként meghatározzuk a kezdeti eseményt. Ezt követi a fa közvetlen elágazásainak felvázolása, majd addig folytatjuk az analízist, míg el nem jutunk a különbözö események lehetséges végső következményeihez. 


\subsection{Csokornyakkendő elemzés}

A csokornyakkendő-analízis alkalmazása olyan esetekben hatásos, amikor a menynyiségi meghatározás nem lehetséges vagy nem szükséges. A logikai ábra formája a férfiak által közkedvelt csokornyakkendöre hasonlít - innen ered az elemzés elnevezése is. Az ábra közepén található a csúcsesemény: ez a csokornyakkendő csomója. A diagram bal oldalán a hibafa-elemzés helyezkedik el, amely megmutatja a lehetséges okok teljes körét, melyek a csúcsesemény bekövetkezéséhez vezetnek. A függöleges oszlopok azok az intézkedéseket jelölik, amelyeket megtettek a csúcsesemény bekövetkezésének megakadályozására beleértve az eszkalációs hatások megakadályozására tett intézkedéseket is. Jobb oldalán az eseményfa látható, mely demonstrálja a csúcsesemény lehetséges következményeit. A függőleges oszlopok azokra az intézkedésekre utalnak, amelyekkel megakadályozhatók, csökkenthetők a nemkívánatos esemény káros következményei.

A módszerrel azonosíthatók a meghibásodási (vagy baleseti) eseménysorok, megállapítható a meghibásodás oka, illetve a rendszer gyenge pontja(i), továbbá meghatározható a meghibásodás hatása, a rendszer üzembiztonsága.

Összefoglalva a csokornyakkendő módszer lényegében a hibafa és eseményfa öszszekapcsolásán alapszik. A hibafa csúcseseménye a kritikus esemény, az eseményfa kezdeti eseménye ez esetben a másodlagos kritikus esemény lesz [3].

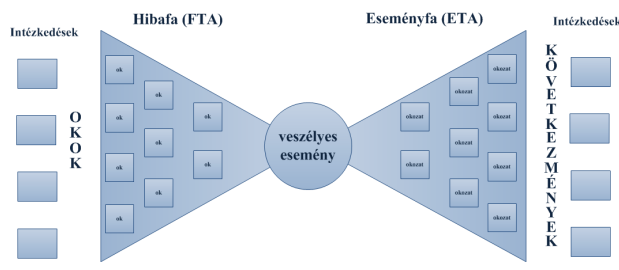

4. ábra. A csokornyakkendö elemzés általános felépitése [3]

\section{Következtetések}

Bármilyen tudományos módszert olyan példán keresztül érdemes bemutatni, tanítani, amely közel áll a hallgatósághoz, amely egyszerüen csak felkelti az érdeklődését, hiszen így könnyen érhető és elsajátítható lesz - akármilyen bonyolult kérdésről is legyen szó.

Ezen tanulmány esetében sem utolsó szempont volt az, hogy laikusok, és természetesen az első számú célközönség, az egyetemi hallgatók számára is könnyen érthető, követhető legyen a bemutatott vizsgálat, illetve annak menete, tulajdonságai és jelentősége. E cél elérése érdekében történt a vizsgált példa választása, amelyet nagy valószínűséggel minden egyetemi hallgató saját bőrén vagy környezetében, baráti társaságában, de valamilyen módon biztosan megtapasztalt.

Tehát a vizsgán történő bukás mint nem-kívánt (csúcs)esemény teljes körü kockázati elemzése, valamint az ehhez vezető okok elkerülése lehetővé teszi a hallgatók számára, hogy a további tanulmányaik során elkerüljék eme nemkívánatos esemény bekövetkezését. Például a bemutatott kockázatelemzési eljárások elsajátításával.

\section{Szakirodalmi hivatkozások}

[1] Pokorádi László: Mátrixalgebrai hibafaérzékenységelemzés, Miskolci Egyetem, Multidiszciplináris tudományok, 1. kötet (2011) 1. szám, 103-110.

[2] Tráj Krisztina: Kockázati ok meghatározó módszerek - Miért bukunk a vizsgán?, TDK dolgozat, ÓE-BGK, Budapest. 2014. 31. (Konzulens: Pokorádi László)

[3] Tráj Krisztina: A „bow-tie” modell szemléltetése - Csokornyakkendö a vizsgákra, TDK dolgozat ÓE-BGK, Budapest. 2014. 21. (Konzulens: Pokorádi László) 